\title{
Occurrence and characterization of a severe isolate of Watermelon mosaic virus from Argentina
}

Article in European Journal of Plant Pathology · March 2016

DOI: $10.1007 /$ s10658-016-0904-z

CITATION

1

5 authors, including:

\section{Maria Cecilia Perotto}

Instituto Nacional de Tecnología Agropecuaria

16 PUBLICATIONS 78 CITATIONS

SEE PROFILE

\section{Vilma Cecilia Conci}

Instituto Nacional de Tecnología Agropecuaria

42 PUBLICATIONS 295 CITATIONS

SEE PROFILE
READS

59
Marcos Celli

Instituto Nacional de Tecnología Agropecuaria 18 PUBLICATIONS 66 CITATIONS

SEE PROFILE

Some of the authors of this publication are also working on these related projects:

Project

Increase of competitiveness, with sustainability and social equity, in differentiated fresh vegetables production systems View project

Project Vegetable viruses View project 


\section{Occurrence and characterization of a severe isolate of Watermelon mosaic virus from Argentina}

\section{María Cecilia Perotto, M. G. Celli, E. A. Pozzi, C. E. Luciani \& V. C. Conci}

\section{European Journal of Plant Pathology} Published in cooperation with the European Foundation for Plant Pathology

ISSN 0929-1873

Eur J Plant Pathol

DOI 10.1007/s10658-016-0904-Z
Volume 144 No. 4 April 2016 ONLINE Flist

European Journal of Plant Pathology

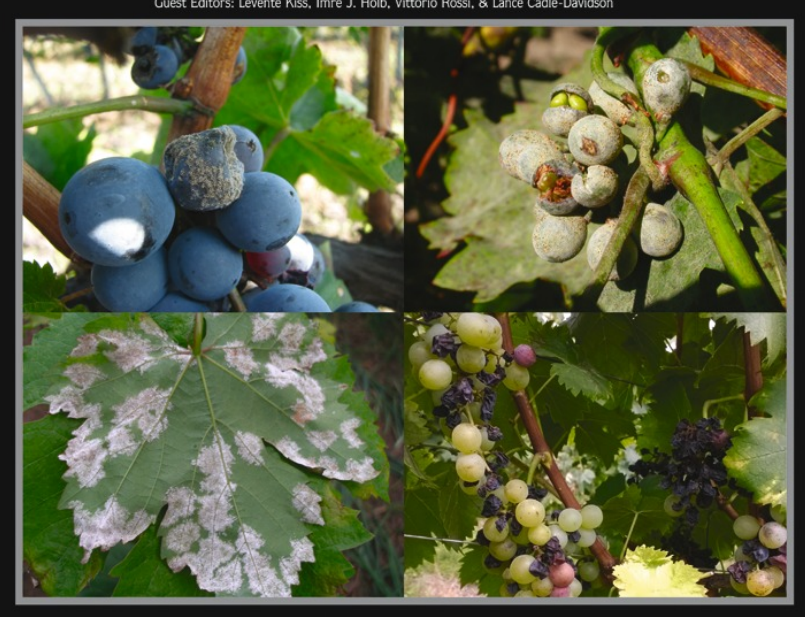

Springer in cooperation with European Foundation for Plant Pathology 
Your article is protected by copyright and all rights are held exclusively by Koninklijke Nederlandse Planteziektenkundige Vereniging. This e-offprint is for personal use only and shall not be self-archived in electronic repositories. If you wish to self-archive your article, please use the accepted manuscript version for posting on your own website. You may further deposit the accepted manuscript version in any repository, provided it is only made publicly available 12 months after official publication or later and provided acknowledgement is given to the original source of publication and a link is inserted to the published article on Springer's website. The link must be accompanied by the following text: "The final publication is available at link.springer.com". 


\title{
Occurrence and characterization of a severe isolate of Watermelon mosaic virus from Argentina
}

\author{
María Cecilia Perotto • M. G. Celli • E. A. Pozzi • \\ C. E. Luciani • V. C. Conci
}

Accepted: 9 March 2016

(C) Koninklijke Nederlandse Planteziektenkundige Vereniging 2016

\begin{abstract}
More than 50 viruses have been reported in cucurbit crops worldwide. In Argentina, cucurbit viruses have been associated with important yield losses. The most prevalent and widespread potyvirus is Watermelon mosaic virus (WMV). WMV was detected in Argentina in all cucurbit species with high incidence. In this study, a WMV isolate (WMV 1 SDE FF) was obtained from a naturally infected squash associated with a severe outbreak on melon and squash crops in an important cucurbit growing area in Santiago del Estero province (Argentina), during a survey conducted in November 2012. The fully sequenced WMV 1 SDE FF genome consists of 10,027 nucleotides and shares $96 \%$ nt identity and $98 \%$ aa identity with the French isolates JF273464.1|C07-014 and EU660581.1|FMF00-LL1 of the WMV molecular group 3. Using the recombination detection program RDP4, two statistically significant recombination events were identified: event 1 , an 830-nt long recombinant fragment in the putative $\mathrm{P} 1$ coding region, and event 2 ,
\end{abstract}

M. C. Perotto $(\bowtie) \cdot$ E. A. Pozzi · C. E. Luciani •

V. C. Conci •

Instituto Nacional de Tecnología Agropecuaria, Instituto de Patología Vegetal (INTA-IPAVE), Camino 60 cuadras km 5,5, (X5020ICA) Córdoba, Argentina

e-mail: perotto.cecilia@inta.gob.ar

M. C. Perotto

e-mail: mcecilia.perotto@gmail.com

M. C. Perotto - M. G. Celli • V. C. Conci •

Consejo Nacional de Investigaciones Científicas y Técnicas (CONICET), Camino 60 cuadras km 5,5, (X5020ICA) Córdoba, Argentina a 4071-nt recombinant fragment detected across the HC Pro, P3 and CI coding regions. The putative parental sequences detected for event 1 were the EU660586.1 FBR04-37 (major parent) and JF273468.1|C07-284 (minor parent), both from France. Putative parental sequences for event 2 were JX079685.1| WMV-ShanXi (major parent) and HQ384216.1|Dendrobium (minor parent), from China and USA, respectively. To our knowledge, this is the first complete genome of an Argentine WMV isolate. Our results provide evidence that WMV 1 SDE FF is the causal agent of the strong outbreak reported in melon and squash fields in recent years.

Keywords WMV.Cucurbitaceae $\cdot$ Virus recombination $\cdot$ Phylogenetic analysis

Cucurbit crops are affected by more than 50 different viruses from several different taxonomic groups. Viral diseases have been considered the main limiting factor in terms of yield and fruit quality in major cucurbit crops worldwide (Lecoq and Desbiez 2012; Lecoq et al. 1998; Zitter et al. 1996). In Argentina, the main cultivated cucurbits are squash (Cucurbita moschata), pumpkin (Cucurbita pepo), and melon (Cucumis melo) (FAOSTAT 2013).

To date, four of the most common and prevalent plant viruses worldwide all transmitted by aphids, were reported in Argentina. Three of those viruses belong to the genus Potyvirus: Watermelon mosaic virus (WMV), Papaya ringspot virus (PRSV) and Zucchini yellow mosaic virus (ZYMV) the remaining one, Cucumber mosaic 
virus (CMV), belongs to the genus Cucumovirus, In the earliest reports, detection was confirmed by serological and differential host assays. WMV was first detected in 1971 (Nome et al. 1974) and since then its presence was always confirmed in all surveys conducted in Argentina. Thus, WMV has become an important threat for production (Gracia and Feldman 1986). PRSV was detected in 1987 from samples of C. moschata in Santiago del Estero (Feldman and Gracia 1992). ZYMV and CMV were detected in squash (C. maxima and C. pepo) and in melon (C. melo) (Gracia 2000; Gracia and Feldman 1986).

Since 2011, the most important growing cucurbit areas of Argentina have been surveyed every year. The presence of viruses was confirmed for the first time by examining symptomatic plants using molecular tests. In 2012 melon and squash plants with severe mosaic, leaf deformation, blistering and vein clearing were observed in production areas of Santiago del Estero province, where a significant effect on fruit yield and quality was recorded. Later a similar situation occurred in 2014 with melon and squash in Cuyo region. In both cases, WMV was detected in all symptomatic plants by double antibody sandwich, enzyme-linked immunosorbent assay (DAS ELISA) and confirmed by Reverse transcription-polymerase chain reaction (RT-PCR) (Moreno et al. 2004) using specific primers in all symptomatic plants tested. The presence of WMV was detected at high frequencies $98 \%$ in 2012 and $100 \%$ in 2014 from 91 and 150 symptomatic plants respectively, in all cucurbit species. WMV has been the most prevalent and widespread virus found in all cucurbit growing regions in Argentina since the earliest record (unpublished data). In addition, a DAS-ELISA test was performed for the samples collected, using antisera against ZYMV, PRSV, CMV, Squash mosaic virus (SqMV) and Cucurbit yellow stunting disorder virus (CYSDV). The serological testing kits were all commercial antisera specific from Bioreba AG (Switzerland). In order to test the putative presence of other viruses, PCR was performed with universal primers for Begomovirus and RTPCR was used with specific primers for Cucurbit aphidborne yellows virus (CABYV) and Cucumber vein yellowing virus (CVYV). The presence of PRSV, ZYMV and CMV was possible to detect in very low percentage, ranging from $2 \%$ to $17 \%$.

Electron microscope observation of leaf dips from symptomatic plant revealed the presence of a virus with filamentous particles, and ultra-thin leaf sections showed cylindrical inclusions typically described for potyvirus. To date, four types of cylindrical inclusions have been recognized. Viruses inducing these types of inclusions have been separated into four subdivisions according to Edwardson (1992). Based on this classification, the WMV Argentinian isolate (WMV 1 SDE FF) belongs to type 3 , showing pinwheels with scrolls and laminated aggregates presented in the cytoplasm of the infected host cells (not shown).

The aim of this work was to molecularly characterize the pathogen responsible for this severe disease in Argentina. A phylogenetic and recombination analysis was performed to analyze the sequence of the WMV isolate. Leaves of naturally infected plants were collected from a field-grown squash showing typical virus symptoms (Fig. 1). Total RNA was extracted from $100 \mathrm{mg}$ of squash leaf tissue of a WMV-infected plant (WMV 1 SDE FF) using a Qiagen RNA kit. RNA was quantified and $5 \mu \mathrm{g}$ were sent to INDEAR (Genomics and Bioinformatics Platform, INDEAR Inc., Rosario, Argentina) for synthesis of cDNA from polyadenylated RNA followed by deep sequencing using Illumina HiSeq 1500.

The reads of the full-length genome were assembled either de novo or by mapping of the Illumina reads to a reference WMV genome (GenBank NC_006262) using the Mira $v 4$ assembling method with a coverage of 16,454 reads/nt. The complete WMV 1 SDE FF genome sequence consisted of 10,027 nt (GenBank accession number KP164988). It presented a single large open reading frame (ORF), starting at nt 127 and ending at nt 9775 that encodes a large polyprotein with 3215 amino acids (aa). The putative cleavage sites of the genome for the viral-encoded proteinases yield all the 10 characteristic potyviral proteins, include the 11 th protein PIPOwith estimated sizes of 439, 455, 347, 52, 634, 53, 190, 243, 517 and 283 aa for P1, HC-Pro, P3, 6 K1, CI, 6 K2, NIaVPg, VPg Pro, NIb and CP, respectively. The comparison of the complete genomic sequence of WMV 1 SDE FF with those of other WMV available in the GenBank by BLAST analysis showed the highest identity (96\% nt and $98 \%$ aa) with the French isolates, JF273464.1 and EU660581.1.

The virus sequence obtained from the RNA-seq was aligned with 35 sequences retrieved from GenBank (http://www.ncbi.nlm.nih.gov/) and with Soybean mosaic virus (SMV) (accession no. AJ628750) as an outgroup using the algorithm muscle in MEGA6, before conducting the phylogenetic analysis (Tamura et al. 2013). Neighbor-joining trees were constructed using the p-distance method with a bootstrap value of 
Fig. 1 Leaf and fruit symptoms in a WMV-infected plant
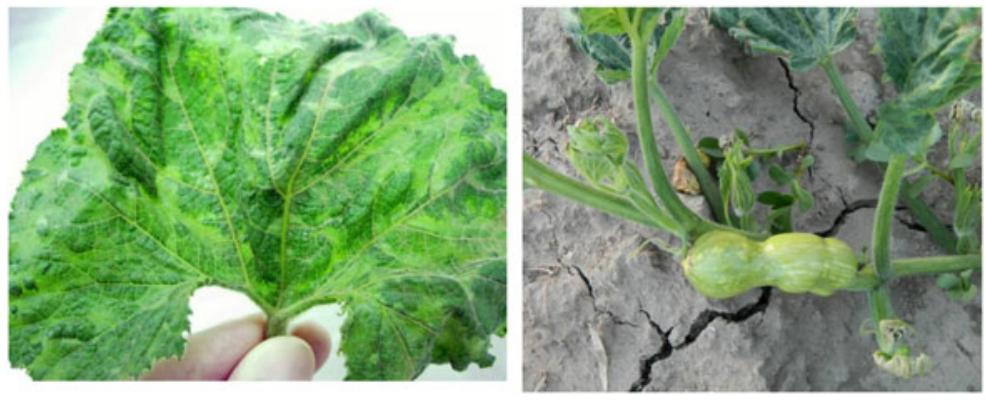

10,000; Maximum Likelihood trees using the TamuraNei model with a bootstrap value of 10,000; Minimum Evolution trees using the Number of differences model with a bootstrap value of 10,000.

Phylogenetic relationships among WMV isolates and the topologies inferred by the different methods (3) were all similar. The WMV isolates formed two distinct major groups based on genetic distances. Group B clustered five isolates and group A clustered the remaining 31 isolates. Group A was further divided into three subgroups: G1, G2 and G3. These three groups were defined by Desbiez et al. (2007). Our phylogenetic analysis showed that WMV 1 SDE FF belongs to subgroup G3 of WMV (Fig. 2). Among G3 isolates, four subgroups were defined, namely EM1 to EM4 (Desbiez et al. 2009); according to that classification, group A (this paper) corresponds to the EM3 subgroup. Intragroup variability in the whole sequences calculated with MEGA 6 was highest within group B $(0.058 \pm 0.002)$, followed by subgroups G3, G1 and $\mathrm{G} 2(0.049 \pm 0.001,0.040 \pm 0.001$ and $0.035 \pm 0.002$, respectively). Intergroup variability was highest between groups B and G1 (0.094 \pm 0.002$)$, being slightly lower between G1 and G2 (0.092 \pm 0.002$)$. The lowest variability for group B was with G3, as expected $(0.085 \pm 0.002)$. Thus, the assignment of isolates to each subgroup is unambiguous with a high bootstrap support.

Little information is available on WMV genetic characterization based on full-length genomes. Furthermore, molecular characterization of this virus is scarce in the American continent. WMV has been reported in USA (HQ384216), Chile (EU660580 and EU660582) and more recently in Venezuela (KC292915) (Desbiez and Lecoq 2008; Romay et al. 2013). Desbiez et al. (2007) reported a sequence of $267 \mathrm{nt}$ of the CP-NIb region from 1994 (DQ845043) of an isolate from Argentina that was included in G1. Another sequence analysis of the NIb$\mathrm{CP}$ region showed that most of the Argentine isolates found nowadays are G3, few of them G2, but none of them are G1 (data not shown). Our results suggest a replacement of G1 with G3 in Argentina, as happened in other countries. Surveys carried out in several countries revealed a rapid replacement of local G1 classic strains (CL) with recently introduced G3 emerging ones (EM) (Fabre et al. 2010; Lecoq et al. 2011; Borodynko et al. 2009; Lecoq and Desbiez 2012; Finetti-Sialer et al. 2012; Kamberoglu et al. 2015). This replacement is very important since group classification is well correlated with differences in symptom intensity; isolates causing very severe symptoms belong to G3, whereas others causing mild symptoms are included in G1 (Desbiez et al. 2009).

The evidence that WMV 1 SDE FF belongs to molecular subgroup G3 is also supported by the fact that it potentially codes for the aa motif KEKET at position 37 in the N-terminal part of the $\mathrm{CP}$, characteristic of molecular G3 isolates (Desbiez et al. 2007).

The Recombination Detection Program v.4.16 (RDP4) was used for recombination analysis (Martin and Rybicki 2000). Recombination events, likely parental isolates of recombinants, and recombination break points were analyzed. Default parameters were used for the seven programs implemented in the RDP4 program: RDP, GENECONV, Chimaera, MaxChi, BOOTSCAN, SISCAN and 3Seq including a Bonferroni corrected $P$ value cutoff of 0.01 . A recombination pattern was considered to be a firm event, and genuine evidence of actual recombination, if detected by four or more of these programs (Wylie and Jones 2009; Kehoe et al. 2014).

When the complete sequence of $35 \mathrm{WMV}$ (retrieved from Genbank) and the WMV 1 SDE FF isolate were analyzed using RDP4, two statistically significant recombination events were identified. Event 1, comprises an 830-nt long recombinant fragment in the putative P1 coding region, and event 2, a 4071-nt recombinant 


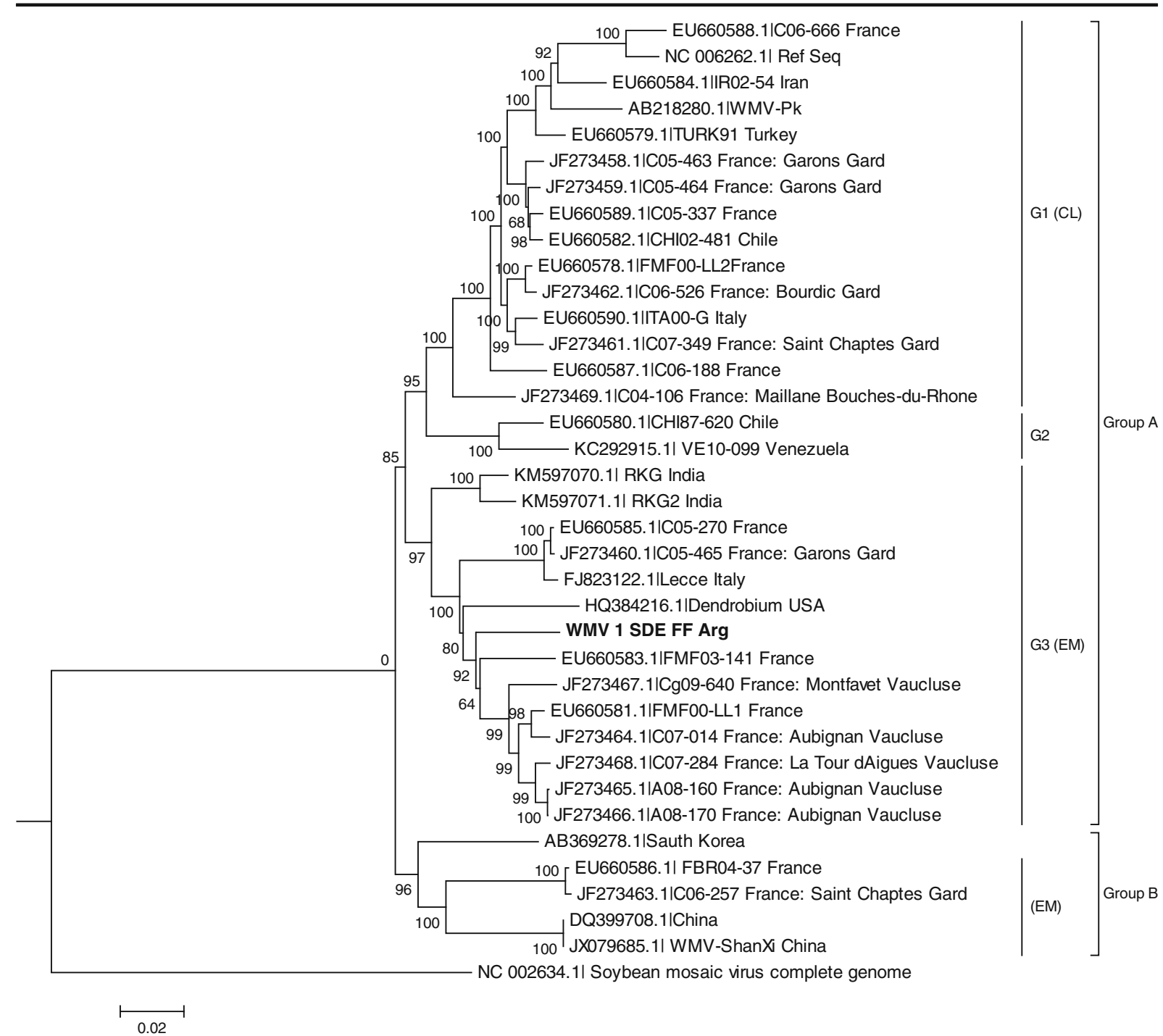

Fig. 2 Neighbor-joining tree illustrating the phylogenetic relationships between WMV 1 SDE FF isolate and 35 published complete nucleotide sequences. The two main clusters (Groups A and B) and subgroups (G1(CL), G2 and G3(EM)) are indicated. The Argentine

fragment detected across the HC Pro, P3 and CI coding regions. The putative parentals detected for event 1 were isolate is shown in bold. SMV was included as an outgroup Bootstrap support (10,000 replicates) is shown next to the branches. Evolutionary analyses were conducted in MEGA6

the EU660586.1| FBR04-37 (major parent) and JF273468.1|C07-284 (minor parent), both from France.

WMV_1_SDE_FF
\begin{tabular}{|l|l|l|l|l||l|l|}
\hline P1 & HC-Pro & P3 & Cl & Nla & Nlb & CP \\
\hline
\end{tabular}
JF273468.1IC $07-284$

\section{HQ384216.1IDendrobium}

Fig. 3 Analysis of recombination in full-length sequence of an WMV isolate from Argentina. Two recombination events were detected. The location of each potyvirus gene is shown (top). The different shadings indicate the viruses that supplied the different regions with the sites and sizes of recombination patterns within them as assessed by six recombination-detection algorithms (RDP4 program) 
Putative parental sequences for event 2 were JX079685.1| WMV-ShanXi (major parent) and HQ384216.1|Dendrobium (minor parent), from China and USA, respectively. In both events the major parentals belong to Group B while the minor parentals belong to G3. Both recombination events were detected using the RDP4 program and were positive for six out of seven algorithms in both cases. The recombination breakpoints (Rbps) were identified by $\operatorname{RDP}\left(P=8,163 \times 10^{-17}\right)$, GENECONV $\left(1211 \times 10^{-16}\right)$, BootScan $\left(2893 \times 10^{-17}\right)$, Maxchi $\left(1794 \times 10^{-11}\right)$, Chimaera $\left(4316 \times 10^{-06}\right)$ and SiScan $\left(9852 \times 10^{-17}\right)$ for event 1 . Similar results were obtained for event 2 , 3Seq $\left(P=8,932 \times 10^{-101}\right)$, GENECONV $\left(1045 \times 10^{-05}\right)$, BootScan $\left(5223 \times 10^{-06}\right)$, Maxchi $\left(3139 \times 10^{-12}\right)$, Chimaera $\left(2001 \times 10^{-09}\right)$ and SiScan $\left(8601 \times 10^{-20}\right)$. The sequences of the C07-014, FMF00LL1 isolates show the same recombination event 2 . As expected, our isolate shares the highest identity score with those isolates that were also confirmed by SDT 1.2 software JF273464.1|C07014 96.1\% and EU660581.1|FMF00LL1_France $96.0 \%$ (Fig. 3).

In this study, we report the biological and molecular characterization of a WMV isolate, named WMV 1 SDE FF (accession KP164988), being the first complete genome of an Argentinian isolate. Our results provide evidence that WMV 1 SDE FF is associated with the strong outbreak reported in last years in melon and squash fields and that it is a recombinant of molecular emerging strain of the virus. We do not have any information on the temporal evolution of WMV populations in the country or how it was introduced into Argentina. Further studies should be planned and carried out to control this important disease in the cucurbit growing areas in Argentina.

Acknowledgments We thank Agr. Eng. Fernando Fernandez, EEA-Santiago del Estero-INTA, for kindly collecting squash samples.

\section{References}

Borodynko, N., Hasiow-Jaroszewska, B., Rymelska, N., \& Pospieszny, H. (2009). Watermelon mosaic virus reported for the first time in Poland. Plant Pathology, 58, 783.

Desbiez, C., \& Lecoq, H. (2008). Evidence for multiple intraspecific recombinants in natural populations of Watermelon mosaic virus (WMV, Potyvirus). Archives of Virology, 153(9), 1749-1754. doi:10.1007/s00705-008-0170-2.
Desbiez, C., Costa, C., Wipf-Scheibel, C., Girard, M., \& Lecoq, H. (2007). Serological and molecular variability of watermelon mosaic virus (genus Potyvirus). Archives of Virology, 152(4), 775-781. doi:10.1007/s00705-006-0899-4.

Desbiez, C., Joannon, B., Chandeysson, C., \& Lecoq, H. (2009). Emergence of new strains of Watermelon mosaic virus in South-eastern France : Evidence for limited spread but rapid local population shift. Virus Research, 141, 201-208.

Edwardson, J. R. (1992). Inclusion bodies. Archives of Virology. Supplementum, 5, 25-30.

Fabre, F., Chadoeuf, J., Costa, C., Lecoq, H., \& Desbiez, C. (2010). Asymmetrical over-infection as a process of plant virus emergence. Journal of Theoretical Biology, 265(3), $377-388$.

FAOSTAT (2013) Food and Agriculture Organization of the United Nations. Statistics Division. http://faostat3.fao.org. Accessed XX June 2015.

Feldman, J. M., \& Gracia, O. (1992). Un nuevo virus de cucurbitáceas en Argentina: el virus de la mancha anillada de la papaya. Revista de Investigaciones Agropecuarias, 23, 63-67.

Finetti-Sialer, M. M., Mascia, T., Cillo, F., Vovlas, C., \& Gallitelli, D. (2012). Biological and molecular characterization of a recombinant isolate of Watermelon mosaic virus associated with a watermelon necrotic disease in Italy. European Journal of Plant Pathology, 132(3), 317-322.

Gracia, O., \& Feldman, J. M. (1986). Virus identificados en cultivos de cucurbitáceas. IDIA, 445-448, 1-6.

Gracia, O. (2000). First report of Zucchini yellow mosaic virus in Argentina. Plant Disease, 84, 371.

Kamberoglu, M. A., Desbiez, C., \& Caliskan, A. F. (2015). Characterization of an emerging 1solate of watermelon mosaic virus in Turkey. International Journal of Agriculture and Biology, 17, 211-215.

Kehoe, M. a., Coutts, B. A., Buirchell, B. J., \& Jones, R. A. C. (2014). Split Personality of a Potyvirus: To Specialize or Not to Specialize? PloS One, 9(8), e105770.

Lecoq, H., Wisler, G., \& Pitrat, M. (1998). Cucurbit viruses: The classics and the emerging. In J. D. McCreight (Ed.), Cucurbitaceae '98: Evaluation and enhancement of cucurbit germplasm (pp. 126-142). Alexandria: ASHS.

Lecoq, H., Fabre, F., Joannon, B., Wipf-Scheibel, C., Chandeysson, C., Schoeny, a., \& Desbiez, C. (2011). Search for factors involved in the rapid shift in Watermelon mosaic virus (WMV) populations in South-eastern France. Virus Research, 159(2), 115-123.

Lecoq, H., \& Desbiez, C. (2012). Viruses of cucurbit crops in the Mediterranean region: an ever-changing picture. Advances in Virus Research, 84, 67-126. doi:10.1016/B978-0-12394314-9.00003-8.

Martin, D., \& Rybicki, E. (2000). RDP: detection of recombination amongst aligned sequences. Bioinformatics, 16, $562-563$.

Moreno, I. M., Malpica, J. M., Díaz-Pendón, J. A., Moriones, E., Fraile, A., \& García-Arenal, F. (2004). Variability and genetic structure of the population of watermelon mosaic virus infecting melon in Spain. Virology, 318(1), 451-460.

Nome, S. F., March, G. J., \& Giorda, L. M. (1974). Disminución de la productividad de plantas de zapallito de tronco (Cucurbita máxima Duch var. zapallito (Carr. Millán) 
infectadas con el virus del mosaico de la sandía, raza 2 (Watermelon Mosaic Virus-2). IDIA, 321-324, 26-31.

Romay, G., Lecoq, H., \& Desbiez, C. (2013). First Report of Watermelon mosaic virus Naturally Infecting Cucumis anguria. Plant Disease, 97(11), 1515.

Tamura, K., Stecher, G., Peterson, D., Filipski, A., \& Kumar, S. (2013). MEGA6: Molecular Evolutionary Genetics Analysis version 6.0. Molecular Biology and Evolution, 30, 2725-2729.

Wylie, S. J., \& Jones, R. A. C. (2009). Role of recombination in the evolution of host specialization within bean yellow mosaic virus. Phytopathology, 99(5), 512-518.

Zitter, T. A., Hopkins, D. L., \& Thomas, C. E. (1996). Compendium of cucurbit diseases. St. Paul: APS Press. 